\title{
A Dynamics of Macro Elements Content in Eutric Podzoluvisols for Separation of Wastewater under Jerusalem Artichokes
}

\author{
Vasyl Lopushniak ${ }^{1}$, Halyna Hrytsuliak ${ }^{2 *}$, Valentina Gamayunova ${ }^{3}$, \\ Natalia Kozan', Elina Zakharchenko ${ }^{5}$, Yurii Voloshin², \\ Halyna Lopushniak ${ }^{6}$, Miroslava Polutrenko ${ }^{2}$, Yulia Kotsyubynska ${ }^{4}$ \\ 1 National University of Life and Environmental Sciences of Ukraine, Heroiv Oborony 15, Kyiv, Ukraine \\ 2 Ivano-Frankivsk National Technical University of Oil and Gas, Vulytsya Karpat-s'ka, 15, Ivano-Frankivsk Oblast, \\ 76000, Ivano-Frankivsk, Ukraine \\ ${ }^{3}$ Mykolayiv National Agrarian University, Mykolaiv, Heorhiia Honhadze St, 9, Mykolaiv Oblast, 54000, Mykolaiv, \\ Ukraine \\ ${ }^{4}$ Ivano-Frankivsk National Medical University, Halytska Str. 2, 76018, Ivano-Frankivsk, Ukraine \\ ${ }^{5}$ Sumy National Agrarian University, Herasima Kondratieva St, 160, Sumy Oblast, 40000, Sumy, Ukraine \\ ${ }^{6}$ Kyiv National Economics University named after Vadym Hetman, Peremohy Ave, 54/1, 03057, Kyiv, Ukraine \\ * Corresponding author's email: gritsulyaka@ukr.net
}

\begin{abstract}
The application of fertilizers based on sewage sludge significantly affects the formation of the nitrogen fund of sod-podzolic soil, as well as changes in the content of mobile compounds of phosphorus and potassium exchange. The application of such fertilizer under Jerusalem artichoke has a positive effect on the nitrogen content of alkaline hydrolyzed compounds, in particular on increasing the content of mineral and alkaline hydrolyzed nitrogen fractions. The application of sewage sludge at a dose of $20-40 \mathrm{t} / \mathrm{ha}$ and the appropriate compensatory dose of mineral fertilizers at the rate of $\mathrm{N}_{90} \mathrm{P}_{90} \mathrm{~K}_{90}$ helps to increase the content of ammonium nitrogen compounds from 16 to $20-22 \mathrm{mg} / \mathrm{kg}$ of soil in the upper $(0-20 \mathrm{~cm})$ layer $-28 \%$ prevails over the control variant, as well as the content of nitrate nitrogen compounds in the layer $0-40 \mathrm{~cm}$ from 1.70 to $2.52-2.64 \mathrm{mg} / \mathrm{kg}$ of soil. The ratio of the content of alkaline hydrolyzed nitrogen compounds to the nitrogen content of mineral compounds in the experimental conditions changes insignificantly, which indirectly indicates a relatively stable value of this indicator, which changes little under the influence of fertilizers. The application of sewage sludge as a fertilizer significantly affects the change in the content of mobile phosphorus compounds and potassium exchange compounds in the upper $(0-40 \mathrm{~cm})$ layer of the soil. However, from a depth of $60 \mathrm{~cm}$, their content decreases sharply and approaches the initial values of the control version. Depending on the application of fertilizers, the indicators of the coefficient of concentration of macronutrients in the soil change significantly, which reflects the ratio of the content of the element in the soil to its content in the control variant. As the rate of sewage sludge increases, the element concentration coefficient increases from 1.27 in the variant with the application of only mineral fertilizers to 2.36 for potassium and for phosphorus - from 1.02 to 1.31 . There is a close correlation between the content of phosphorus and potassium in the soil and the coefficients of their concentration. This relationship reflects the multiple coefficient of determination, which for phosphorus and potassium is $\mathrm{R}^{2}=0.69$ and $\mathrm{R}^{2}=0.90$, respectively. The use of fertilizers in the form of compost with sewage sludge and straw of cereals causes similar trends as the introduction of uncomposted sewage sludge. However, this effect has less radical impact with lower absolute nutrient content compared to the introduction of fresh sewage sludge. The application of sewage sludge in the form of compost and uncomposted form contributes to a significant increase in the content of macronutrients in the soil, providing an improvement in the mineral nutrition of cultivated plants, including Jerusalem artichokes.
\end{abstract}

Keywords: nitrogen, phosphorus, potassium, concentration factor, compost. 


\section{INTRODUCTION}

In the world and in Ukraine, there is a growing interest in growing crops for energy purposes, which include areas of mostly unproductive degraded soils outside of crop rotations. With high biological productivity, such crops respond well to the application of fertilizers, including organic, which not only improve the nutrient regime of the soil, but also contribute to the implementation of its bioproductive and environmental functions. With increasing competition with the cultivation of food crops and limited resources of traditional types of organic fertilizers in agriculture, there is a need to find alternative sources of replenishment of organic raw materials for application as fertilizer for bioenergy crops.

One of the promising areas for solving such problems is the use of non-traditional types of organic fertilizers of sewage sludge, which has a high fertilizing potential and can be used in energy systems of energy crops in compliance with certain environmental requirements.

Sewage sludge (SS), which accumulates in excess in many countries, including Ukraine, has prospects for use in the agricultural sector as a fertilizer, provided that the environmental safety requirements of such use and the permissible content of heavy metals and other pollutants. (Hrytsuliak \& Lopushniak, 2017, Krutyakova, et al., 2020, Hetmanenko, 2016, Kholodna, 2016, Berdnikov et al., 2019, Yang et al, 2015, Rossini et al, 2019, Hospodarenko, 2015). Sewage sludge contains a necessary for full growth and development of plants (Onyshchuk et al., 2004, Lopushniak et al, 2021, Hetmanenko \& Skrylnyk, 2017, Lamastra, et al, 2018, Geletukha et al., 2021). This raw material resource should be considered as an important part of energy environmentally friendly biological technologies for growing crops, especially energy.

A promising area of environmentally friendly use of sewage sludge is also the production of compost with its addition and other organic materials, in particular, cereal straw and more. The use of such composts enhances the humus-forming ability of the soil due to the receipt of additional organic matter and intensification of the development of beneficial microflora, which improves the mineral nutrition of plants, which provides increased bioproductivity of agrophytocenoses (Hospodarenko, 2015, Dubovyi et al., 2018, Ruf, 2019, Kalenskaya et al., 2019)
An effective method of wastewater disposal is to use them as fertilizers in compliance with regulatory requirements for the content of pollutants, which helps to solve several problems: reducing the intensity of accumulation in sludge maps of SS and ensuring the flow of organic matter and nutrients to the soil (Madzhd et al., 2017, Yakymenko, 2001, Krutyakova, 2020 Lopushniak et al, 2021). Due to the fact that there is a risk of man-made pollution and contamination of trophic chains for the introduction of SS for food crops, its use is for energy crops grown on marginal lands, improves agrochemical, agrophysical indicators of soil cover, provides better implementation of environmental functions. and also causes an increase in the content of organogenic elements of mineral nutrition (Berdnikov et al., 2019, Karbivska et al., 2020).

In recent years, there has been a growing interest in growing Jerusalem artichokes as a potential energy crop. This interest in this crop was during the energy crisis of the 1970s, which prompted her research to produce biofuels, as terrestrial plant biomass and tubers can be used for this purpose. (Alla at al, 2014, Onyshchuk, 2004, Sloboda P., Lopushnyak V., 2017). Due to the long-term study of growing conditions, Jerusalem artichoke is considered a very promising specific energy crop that could grow well on marginal lands without competing for highly productive arable land with grain production. Given its tolerance for environmental stresses, including drought and salinity, and strong resistance to plant diseases and pests, Jerusalem artichoke can be considered an alternative energy crop, including miscanthus, which is intensively studied in the United States and Europe. Jerusalem artichoke can be used not only as a raw material for the production of biomass and biofuels (ethanol) and biologically based chemicals, but also as a value-added product for the production of feed, food, sources of bioactive ingredients and more. The process of its bioprocessing is economically competitive (Long, et al, 2016; Long Xiao-Hua et al, 2010; Linxi Yang, et al 2015, Yang et al., 2020). An important aspect of promoting Jerusalem artichoke culture is its successful use in combating erosion and desertification in some provinces of China. (Yang, et al, 2020). At the same time, some researchers consider Jerusalem artichoke as an invasive species, the spread of which is a threat to biodiversity in ruderal and agricultural environments (Pacanoski \& Mehmeti, 2020). This 
indicates, on the one hand, the high competitiveness of this species and environmental plasticity, and on the other hand, the need to comply with the technological conditions of its cultivation and control over its number and harmfulness.

The study of the use of sewage silt under Jerusalem artichoke showed promising opportunities for its use for phytosequestration of metals metals that fall into the category of dangerous from sewage silt that are transformed in the soil. It is established that increasing the doses of sewage sludge significantly increases the yield of Jerusalem artichoke biomass, and also has a significant effect on the translocation of heavy metals in the aboveground parts of plants (Antonkiewicz et al., 2018).

It is known that growing conditions significantly affect the productivity and quality of products, including tuberous plants (Lopushniak \& Hrytsuliak, 2021; Sloboda P., Lopushnyak V., 2017; Sobol et al., 2020) However, there are relatively few reports in the available literature on improving soil characteristics, including changes in organogenic nutrients in Jerusalem artichoke cultivation under the influence of sewage sludge, including compost based on it.

The purpose of the research is to establish the change in the content of certain organogenic elements of mineral nutrition in sod-podzolic soil with the introduction of different doses of SS and its composts with organic materials under Jerusalem artichokes.

\section{MATERIALS AND METHODS}

Studies to study the effectiveness of sewage sludge under one of the most promising bioenergy crops - Jerusalem artichoke was conducted in a field experiment on sod-podzolic soils of IvanoFrankivsk region (Lopushniak \& Hrytsuliak, 2021).

The soil of the experimental site is eutric podzoluvisols. Clear redistribution of the colloidal fraction of the eluvial and illuvial horizons. Humus-eluvial (HE) horizon up to 18-25 $\mathrm{cm}$, dark gray, lumpy-dusty, loose, with powder $\mathrm{SiO}_{2}$. Eluvial horizon (E) up to $45 \mathrm{~cm}$ yellowishwhitish. The illuvial (I) horizon is marked by a pronounced alternation of layers of whitish sand with dense reddish-brown layers of loam up to 8 $\mathrm{cm}$, hydrolytic acidity $-3.1 \mathrm{mmol} / 100 \mathrm{~g}$ of soil. The content of alkaline hydrolyzed nitrogen compounds was $47 \mathrm{mg} / \mathrm{kg}$ of soil, mobile phosphorus compounds - 64, potassium exchange - $42 \mathrm{mg} / \mathrm{kg}$ of soil (Lopushniak et al., 2021).

The scheme of the experiment consisted of the following options: 1 - control (without fertilizers); $2-\mathrm{N}_{60} \mathrm{P}_{60} \mathrm{~K}_{60} ; 3-\mathrm{N}_{90} \mathrm{P}_{90} \mathrm{~K}_{90} ; 4$. - SS $20 \mathrm{t} /$ ha $+\mathrm{N}_{50} \mathrm{P}_{52} \mathrm{~K}_{74} ; 5-\mathrm{SS} 30$ t/ha $+\mathrm{N}_{30} \mathrm{P}_{33} \mathrm{~K}_{66} ; 6-\mathrm{SS}$ $40 \mathrm{t} / \mathrm{ha}+\mathrm{N}_{10} \mathrm{P}_{14} \mathrm{~K}_{58} ; 7$ - compost (SS + straw in the ratio (3: 1) $20 \mathrm{t} / \mathrm{ha}+\mathrm{N}_{50} \mathrm{P}_{16} \mathrm{~K}_{67} ; 8$ - compost $\left(\mathrm{SS}+\right.$ straw in the ratio (3: 1)) $30 \mathrm{t} / \mathrm{ha}+\mathrm{N}_{30} \mathrm{~K}_{55}$ (Lopushniak et al., 2021).

SS and composts with a compensatory dose of mineral fertilizers based on the total amount of nutrients introduced in the norm $\mathrm{N}_{90} \mathrm{P}_{90} \mathrm{~K}_{90}$. (Lopushniak \& Hrytsuliak, 2021).

The studies used sewage sludge, which was characterized by the following indicators: humidity $-76 \%$, pH -8.1 , the content of ash elements, nitrogen, phosphorus and potassium was $5.0 \%$, $4.0,3.8$ and 1.6, respectively \% (in terms of absolutely dry matter). Composts with SS and straw of cereals in the ratio $3: 1$ were marked by the following chemical composition: organic matter content $-78 \%, \mathrm{pH}_{\mathrm{HCl}}-7.2$, nitrogen of alkaline hydrolyzed compounds - $200.3 \mathrm{mg} / \mathrm{kg}$ of compost, phosphorus of mobile compounds - 371.2, potassium metabolism - $115.4 \mathrm{mg} / \mathrm{kg}$ of compost. Determination of the chemical composition of non-traditional types of organic fertilizers was determined in the laboratory of analytical support of agrochemical research of Ivano-Frankivsk branch of the Institute of Soil Protection of Ukraine «State Soil Protection» according to generally accepted methods (Yakist gruntu ${ }^{1}, 2008$, Yakist gruntu $^{2}, 2008$, Yaki 2006).

The total area of the research site is $63.0 \mathrm{~m}^{2}$, the accounting area is $35.0 \mathrm{~m}^{2}$.

To assess the nitrogen fund of the soil for the introduction of SS determined the content of various nitrogen compounds in the soil. To determine the peculiarities of the transformation of phosphorus and potassium compounds in the soil, the concentration coefficients of their compounds were determined by the ratio of the content of each element in the experimental variants to its content in the background (option 1). The value of the concentration coefficients indicates the intensity of leaching processes in the soil (Madzhd et al., 2016).

During the period of experimental research during 2016-2020, the content of total nitrogen in the study of the NSC IGA named after ON Sokolovsky was determined in the studied soil; DSTU 4729: 2007. Determination of nitrate 
and ammonium nitrogen in the modification of NSC «IGA named after ON Sokolovsky» (Yakist gruntu ${ }^{1}, 2008$, Yakist gruntu ${ }^{2}$, 2008, Kholodna, 2016). Determination of mobile phosphorus and potassium compounds by the Kirsanov method in the modification of NSC IGA DSTU 4405: 2005 (Yakist gruntu, 2006, Lopushniak \& Hrytsuliak, 2021).

\section{RESULTS}

Studies have shown that the use of fertilizers significantly affected the formation of the nitrogen fund of sod-medium-podzolic soil (Table 1).

In particular, the use of mineral fertilizers at a dose of $\mathrm{N}_{60} \mathrm{P}_{60} \mathrm{~K}_{60}$ contributed to an increase in nitrogen content of alkaline hydrolyzed compounds by $5 \mathrm{mg} / \mathrm{kg}$ of soil in the upper $(0-20 \mathrm{~cm})$ and 2 $\mathrm{mg} / \mathrm{kg}$ in the lower $(20-40 \mathrm{~cm})$ layer, which was 44, 25 and $27.82 \mathrm{mg} / \mathrm{kg}$ of soil (Lopushniak et al., 2021). Increasing the dose of nitrogen with mineral fertilizers helped to increase the nitrogen content of alkaline hydrolyzed compounds in the soil. Application of SS at a dose of 20-40 t/ ha with the corresponding balance dose of mineral fertilizers caused an increase in alkaline hydrolyzed nitrogen compounds by $8.64-11.67$ $\mathrm{mg} / \mathrm{kg}$ in the upper $(0-20 \mathrm{~cm})$ layer of soil and by $3.41-4,99 \mathrm{mg} / \mathrm{kg}$ in the lower $(20-40 \mathrm{~cm})$. Slightly lower growth rates of alkaline nitrogen compounds were provided by the application of composts based on sewage sludge and straw, in the upper layer the content of alkaline nitrogen compounds was 54.34-54.56 in the topsoil and $30.74-31.98 \mathrm{mg} / \mathrm{kg}$ of soil in the lower, which significantly exceeded the indicators of the control option (Lopushniak \& Hrytsuliak, 2021).

Simultaneously with the change in the nitrogen content of nitrate compounds, this contributed to the formation of the content of mineral nitrogen compounds in the soil in the range of $17.74-24.58 \mathrm{mg} / \mathrm{kg}$ of soil $(0-20 \mathrm{~cm})$ layer and $17.65-24.9 \mathrm{mg} / \mathrm{kg}$ soil $(20-40 \mathrm{~cm})$ layer. The highest indicators of the content of mineral nitrogen compounds were recorded in option 6 , where the highest dose of sewage sludge was applied $-40 \mathrm{t} / \mathrm{ha}$ and the corresponding amount of mineral fertilizers $\left(\mathrm{N}_{10} \mathrm{P}_{14} \mathrm{~K}_{58}\right)$ application of composts with SS (options 7 and 8) provided the content of mineral nitrogen compounds in the range of 22.09-22.19 mg/kg of soil (Fig. 1).

It should be noted that despite the wide range of values of nitrogen content of alkaline

Table 1. The content of nitrogen compounds of different fractions in the layer of $0-40 \mathrm{~cm}$ of soil, the average for 2016-2020

\begin{tabular}{|c|c|c|c|c|}
\hline \multirow{4}{*}{ Options } & \multirow{4}{*}{$\begin{array}{l}\text { Soil layer, } \\
\text { sm }\end{array}$} & \multicolumn{3}{|c|}{ The content of different nitrogen fractions in the soil } \\
\hline & & \multirow{2}{*}{$\frac{\text { Ammonium }}{\mathrm{N}_{\mathrm{NH}^{-}}}$} & \multirow{2}{*}{$\frac{\text { Nitrate }}{\mathrm{N}_{\mathrm{NO}^{-}}}$} & \multirow{2}{*}{$\begin{array}{l}\text { Nitrogen of } \\
\text { hydrolyzed } \\
\text { compounds }\end{array}$} \\
\hline & & & & \\
\hline & & \multicolumn{3}{|c|}{$\mathrm{mg} / \mathrm{kg}$ of soil } \\
\hline \multirow{2}{*}{ 1. Without fertilizers (control) } & $0-20$ & \multirow{2}{*}{$\begin{array}{l}16 \\
16\end{array}$} & \multirow{2}{*}{$\begin{array}{l}1.74 \\
1.65\end{array}$} & \multirow{2}{*}{$\begin{array}{l}44.25 \\
27.82\end{array}$} \\
\hline & $20-40$ & & & \\
\hline \multirow{2}{*}{ 2. $\mathrm{N}_{60} \mathrm{P}_{60} \mathrm{~K}_{60}$} & $0-20$ & \multirow{2}{*}{$\begin{array}{l}17 \\
17\end{array}$} & \multirow{2}{*}{$\begin{array}{l}2.65 \\
1.91\end{array}$} & \multirow{2}{*}{$\begin{array}{l}49.01 \\
29.15\end{array}$} \\
\hline & $20-40$ & & & \\
\hline \multirow{2}{*}{ 3. $\mathrm{N}_{90} \mathrm{P}_{90} \mathrm{~K}_{90}$} & $0-20$ & \multirow{2}{*}{$\begin{array}{l}19 \\
18\end{array}$} & \multirow{2}{*}{$\begin{array}{l}2.96 \\
2.48\end{array}$} & \multirow{2}{*}{$\begin{array}{l}50.18 \\
32.10\end{array}$} \\
\hline & $20-40$ & & & \\
\hline \multirow{2}{*}{ 4. $S S-20 \mathrm{t} / \mathrm{ha}+\mathrm{N}_{50} \mathrm{P}_{52} \mathrm{~K}_{74}$} & $0-20$ & \multirow{2}{*}{$\begin{array}{l}20 \\
19 \\
\end{array}$} & \multirow{2}{*}{$\begin{array}{l}2.76 \\
2.28\end{array}$} & \multirow{2}{*}{$\begin{array}{l}52.89 \\
31.23\end{array}$} \\
\hline & $20-40$ & & & \\
\hline \multirow{2}{*}{ 5. SS - 30 t/ha $+\mathrm{N}_{30} \mathrm{P}_{33} \mathrm{~K}_{66}$} & $0-20$ & 20 & 2.42 & 53.87 \\
\hline & $20-40$ & 20 & 2.86 & 32.23 \\
\hline \multirow{2}{*}{ 6. SS - $40 \mathrm{t} / \mathrm{ha}+\mathrm{N}_{10} \mathrm{P}_{14} \mathrm{~K}_{58}$} & $0-20$ & \multirow{2}{*}{$\begin{array}{l}22 \\
21\end{array}$} & \multirow{2}{*}{$\begin{array}{l}2.58 \\
3.98\end{array}$} & \multirow{2}{*}{$\begin{array}{l}55.92 \\
32.81\end{array}$} \\
\hline & $20-40$ & & & \\
\hline \multirow{2}{*}{ 7. Compost (SS + straw (3: 1)) -20 t/ha $+\mathrm{N}_{50} \mathrm{P}_{16} \mathrm{~K}_{67}$} & $0-20$ & \multirow{2}{*}{$\begin{array}{l}20 \\
19\end{array}$} & \multirow{2}{*}{$\begin{array}{l}2.09 \\
1.85\end{array}$} & \multirow{2}{*}{$\begin{array}{l}54.34 \\
30.74\end{array}$} \\
\hline & $20-40$ & & & \\
\hline \multirow{2}{*}{ 8. Compost (SS + straw (3: 1)) $-30 \mathrm{t} / \mathrm{ha}+\mathrm{N}_{30} \mathrm{~K}_{55}$} & $0-20$ & \multirow{2}{*}{$\begin{array}{l}20 \\
19 \\
\end{array}$} & \multirow{2}{*}{$\begin{array}{l}2.19 \\
2.74\end{array}$} & \multirow{2}{*}{$\begin{array}{l}54.56 \\
31.98\end{array}$} \\
\hline & $20-40$ & & & \\
\hline The smallest significant difference is $0.5, \mathrm{mg} / \mathrm{kg}$ of & $0-20$ & 1.01 & 0.2 & 0.9 \\
\hline soil & $20-40$ & 1.0 & 0.1 & 0.5 \\
\hline
\end{tabular}




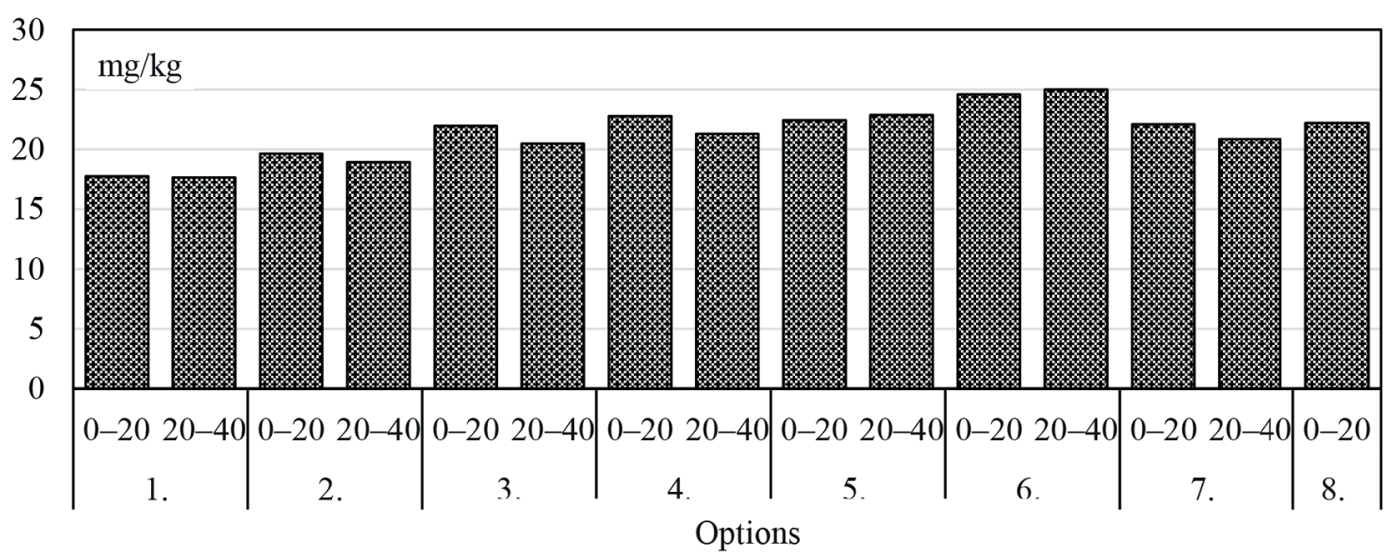

Figure 1. The content of mineral compounds of nitrogen in the layer of 0-40 cm of sod-podzolic soil, the average for 2016-2020

hydrolyzed compounds and mineral compounds, their ratio was 2.3-2.6 in the upper layer and 1.21.4 in the lower $(20-40 \mathrm{~cm})$ and decreased with increasing dose fertilizers. The ratio of the content of alkaline hydrolyzed nitrogen compounds to the nitrogen content of mineral compounds can be considered a relatively stable indicator of soil characteristics, which varies insignificantly depending on the application of fertilizers (Lopushniak \& Hrytsuliak, 2021).

The use of SS and composts based on it led to a significant increase in the content of mobile phosphorus compounds and potassium metabolic compounds in sod-podzolic soil. This increase was observed in all variants of the experiment on the soil profile to a depth of $60 \mathrm{~cm}$. Deeper than $60 \mathrm{~cm}$, the difference in the variants of the experiment was less pronounced, and for phosphorus almost imperceptible (within error) (Lopushniak \& Hrytsuliak, 2021).

The highest values of phosphorus and potassium were recorded in the variants with the introduction of fresh SS and were 90.1 and $96.8 \mathrm{mg} /$ $\mathrm{kg}$ of soil, respectively, mobile compounds of phosphorus and metabolic potassium in the upper $(0-20 \mathrm{~cm})$ layer of soil (variant with the highest SS application rate - option 6. In the subsoil layer $(20-40 \mathrm{~cm})$ the difference was also significant a)

$$
\text { content-of-mobile phosphorus }
$$
compounds, $\mathrm{mg} / \mathrm{kg}$

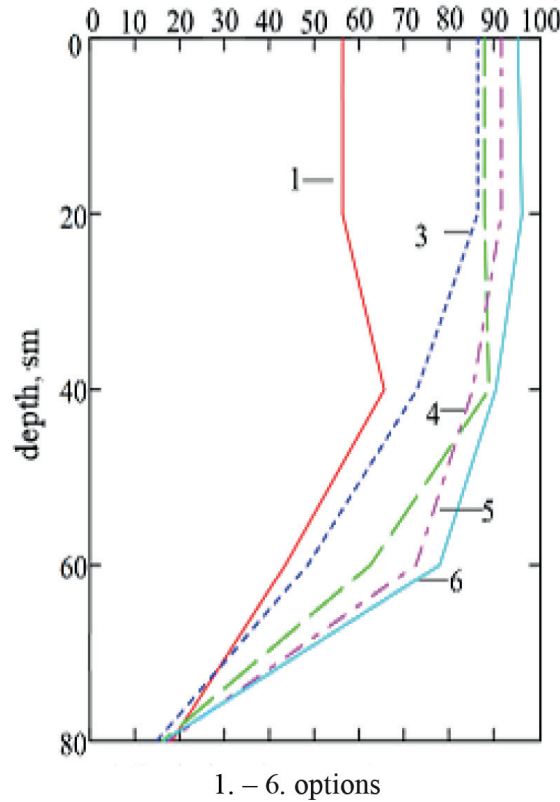

b) content of mobile phosphorus compounds. $\mathrm{mg} / \mathrm{kg}$

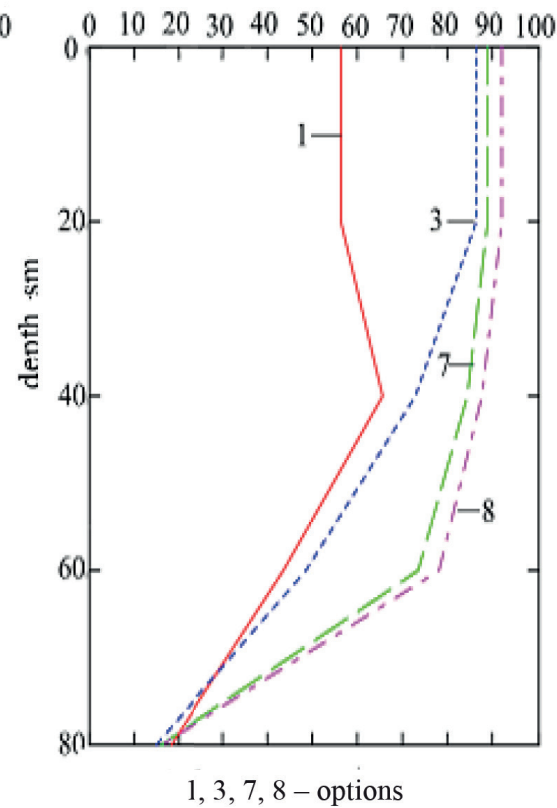

Figure 2. Influence of sewage sludge and compost on its basis on the content of mobile phosphorus compounds in sod-medium-podzolic soil, average for 2016-2020; a) 1.-6. options, b) 1, 3, 7, 8- options 
a)

content-of-metabolic compounds of potassium, $\mathrm{mg} / \mathrm{kg} \cdot$ of - soil

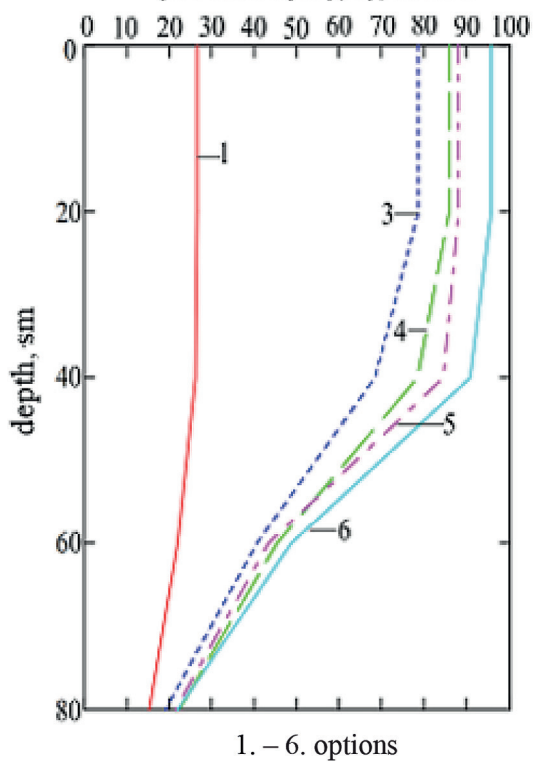

b) content-of -metabolic compounds - of potassium, $\mathrm{mg} / \mathrm{kg} \cdot$ of $\cdot$ soil

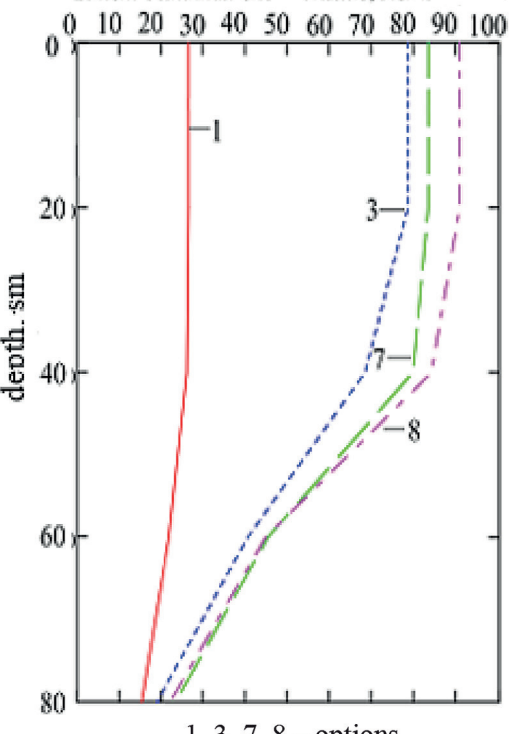

$1,3,7,8-$ options

Figure 3. Influence of sewage sludge and compost on its basis on the content of potassium metabolites in sod-medium-podzolic soil, average for 2016-2020; a) 1. -6. options, b) 1, 3, 7, 8-options

for the experimental variants compared to the control, but the content of mobile phosphorus compounds changed less than the indicators of potassium metabolites. dose $\mathrm{N}_{60-90} \mathrm{P}_{60-90} \mathrm{~K}_{60-90}$ the coefficient of concentration of phosphorus compounds was $1.01-1.17$ in the arable soil layer $(0-20 \mathrm{~cm})$, and the soil profile to a depth of 60 $\mathrm{cm}$ increased and varied in the range of 1.02-1, $15(20-40 \mathrm{~cm})$ (see Fig. 2 and 3).

The highest indicators of the concentration coefficients of phosphorus and potassium compounds were recorded in the options with the introduction of fresh SS, namely option 6 (SS - 40 $\mathrm{t} / \mathrm{ha}+\mathrm{N}_{10} \mathrm{P}_{14} \mathrm{~K}_{58}$ ) and amounted to 1.26 and 2.34 $\mathrm{mg} / \mathrm{kg}$ of soil, respectively, in the upper $20 \mathrm{~cm}$ ) a)
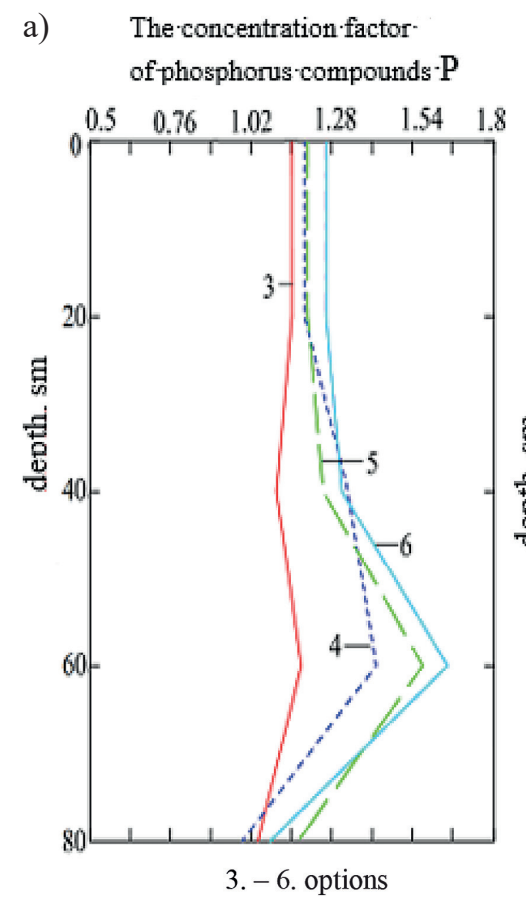

b) The concentration factor of phosphorus compounds $P$

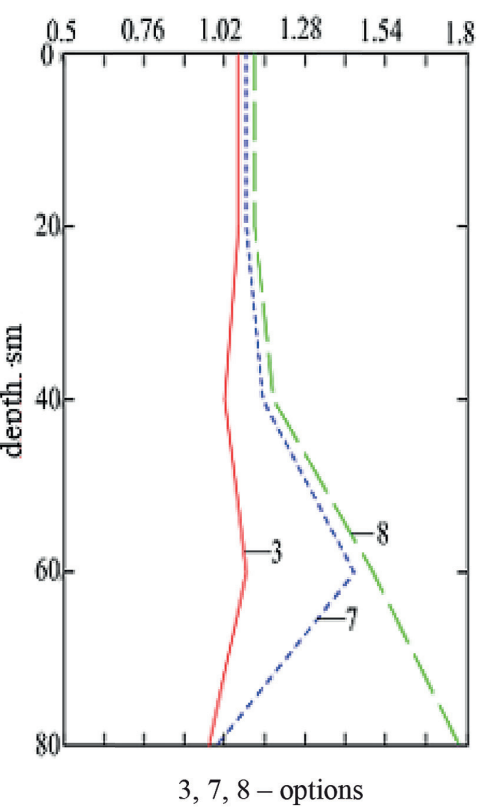

Figure 4. Change in the coefficient of phosphorus concentration in sod-medium-podzolic soil depending on the application of fertilizers, the average for 2016-2020; a) 3. -6. options, b) 3, 7, 8 - options 
a)

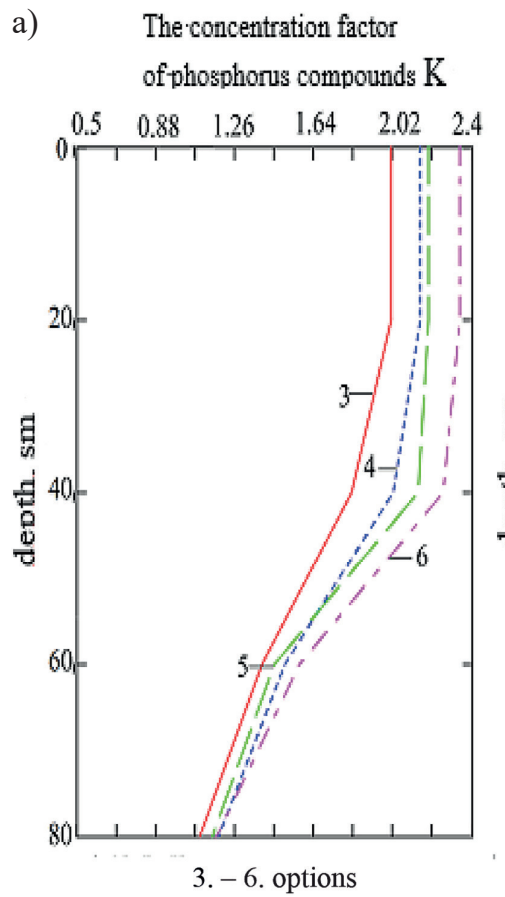

b) The concentration factor of phosphorus compounds $\mathrm{K}$

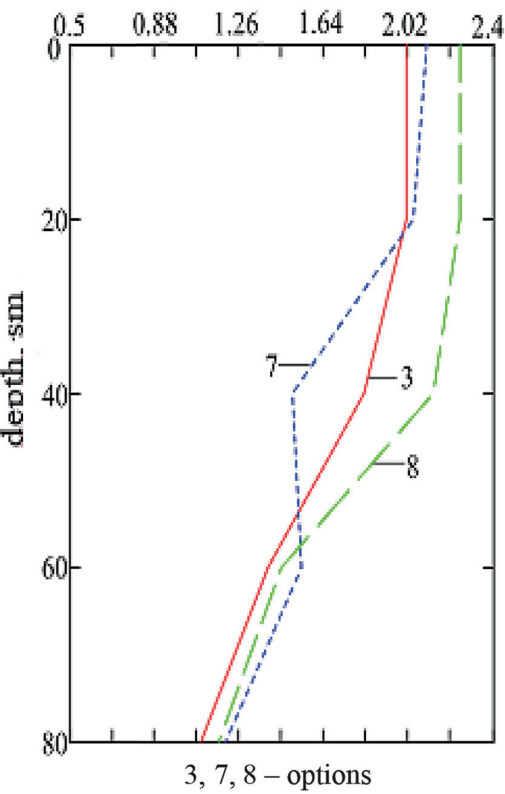

Figure 5. Change in the coefficient of potassium concentration in sod-medium-podzolic soil with the introduction of various forms of fertilizers, the average for 2016-2020; a) 3. -6. options, b) 3, 7, 8 - options

layers of soil. In the subsoil layer $(20-40 \mathrm{~cm})$ of the layer, the concentration coefficient of phosphorus and potassium compounds was 1.31 and 2.26 , respectively. The use of composts based on SS (options 7 and 8) provided the values of the concentration coefficients of phosphorus and potassium compounds in the range of 1.18-1.21 and 2.10-2.25, respectively. The lowest values of the concentration coefficients of phosphorus and potassium compounds were observed in the soil profile at a depth of $60-80 \mathrm{~cm}$, due to a decrease in the content of phosphorus and potassium compounds (Figs. 4 and 5).

According to the results of correlation-regression analysis, it was found that the coefficient of phosphorus concentration (Fig. 6) depends mostly on the content of mobile compounds in the soil with coefficients of determination $\mathrm{R}^{2}=0.69$ and correlation $\mathrm{r}=0.72$.
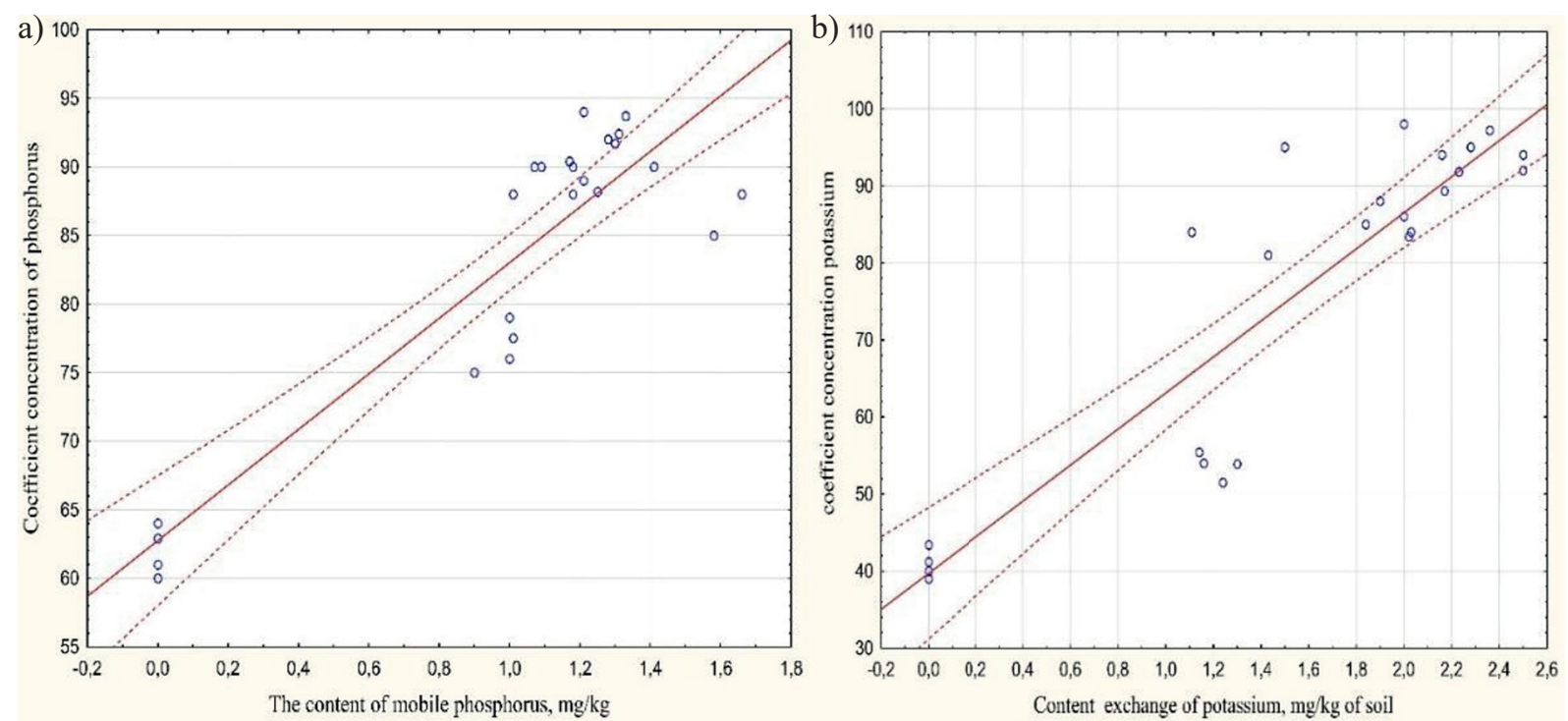

Figure 6. Correlation dependence of the phosphorus concentration factor (a) and potassium (b) from the content of their compounds in sod-podzolic soil 
The multiple regression equation can look like this:

$$
y=62.7482+20.2833 \cdot x
$$

where: $x$ is the content of mobile phosphorus compounds in the soil, $\mathrm{mg} / \mathrm{kg}$ of soil; $y$ is the coefficient of phosphorus concentration.

According to the results of correlation-regression analysis, it was found that the coefficient of potassium concentration depends mostly on the content of its metabolic compounds in the soil with the coefficients of determination and correlation $\mathrm{R}^{2}=0.90, \mathrm{r}=0.93$. The multiple regression equation can look like this:

$$
y=39.7151+23.4049 \cdot x
$$

where: $x$ is the content of potassium metabolites in the soil, $\mathrm{mg} / \mathrm{kg}$ of soil; $y$ is the coefficient of potassium concentration.

\section{CONCLUSIONS}

1. According to numerous studies, Jerusalem artichoke is considered a promising bioenergy crop with diverse uses.

2. Application of SS under Jerusalem artichoke as a fertilizer has a positive effect on the formation of the nitrogen fund of sod-podzolic soil, in particular on increasing the content of different nitrogen fractions. The application of SS at a dose of 20-40 t/ha and the appropriate balance dose of mineral fertilizers (according to the experimental scheme) increases the content of ammonium nitrogen compounds from 16 to $20-22 \mathrm{mg} / \mathrm{kg}$ of soil in the upper layer, which is $20-28 \%$ indicators of the control variant. Also, the introduction of SS increases the content of nitrate compounds of nitrogen in the layer $0-40 \mathrm{~cm}$ from 1.70 to $2.52-2.64 \mathrm{mg} / \mathrm{kg}$ of soil. This trend is positively reflected in the formation of nitrogen content of alkaline hydrolyzed compounds. Because in the conditions of the experiment this indicator increases from 36.0 to $43.0-44.4 \mathrm{mg} / \mathrm{kg}$ of soil.

3. The highest indicators of the content of mineral nitrogen compounds were recorded in the variant with the application of the highest dose of SS - $40 \mathrm{t} / \mathrm{ha}$ and the corresponding amount of mineral fertilizers $\left(\mathrm{N}_{10} \mathrm{P}_{14} \mathrm{~K}_{58}\right)$.
Application of composts with SS and straw of cereals provides the content of mineral nitrogen compounds within $22.2 \mathrm{mg} / \mathrm{kg}$ of soil. The ratio of the content of alkaline hydrolyzed nitrogen compounds to the nitrogen content of mineral compounds in the experimental conditions changes insignificantly, which indirectly indicates a relatively stable indicator of soil characteristics, which changes little under the influence of fertilizers.

4. The application of SS as a fertilizer significantly affects the change in the content of mobile phosphorus compounds and potassium metabolites in the soil. Graphic analysis indicates that up to a depth of $40 \mathrm{~cm}$ the content of these macronutrients increases significantly with the application of fertilizers with SS. However, from a depth of $60 \mathrm{~cm}$, their content decreases sharply and approaches the initial values of the control version. For potassium, a sharp drop in the content of its mobile compounds occurs from a depth of $40 \mathrm{~cm}$, although in the upper layers of the soil $(0-40 \mathrm{~cm})$ this figure exceeds the control of 2.0-2, 3 times.

5. Depending on the application of fertilizers, the indicators of the coefficient of concentration of macronutrients in the soil, which reflects the ratio of the content of the element in the soil to its content in the control variant, change significantly. With increasing SS application rate, the concentration coefficient increases from 1.27 in the variant with the application of only mineral fertilizers to 2.36 for potassium and for phosphorus from 1.02 to 1.31 .There is a close correlation between the content of phosphorus and potassium in the soil and the coefficients of their concentration. This relationship reflects the multiple coefficient of determination, which for phosphorus and potassium is $\mathrm{R}^{2}=$ 0.69 and $\mathrm{R}^{2}=0.90$, respectively.

6 . The use of fertilizers in the form of compost with SS and straw of cereals causes similar trends as the introduction of uncomposted SS. However, this effect has less radical impact with lower absolute nutrient content compared to the introduction of fresh SS

7. The introduction of SS in the form of compost and uncomposted contributes to a significant increase in the content of macronutrients in the soil, improving the mineral nutrition of cultivated plants, including Jerusalem artichokes. 


\section{REFERENCES}

1. Alla N.A., Domokos-Szabolcsy É., El-Ramady H., Hodossi S., Fári M., Ragab M., Taha H. 2014. Jerusalem artichoke (Helianthus tuberosus L.): A review of in vivo and in vitro propagation. International Journal of Horticultural Science, 20(3-4), 131-136.

2. Antonkiewicz J., Kołodziej B., Bielińska E., Witkowicz R., Tabor S. 2018. Using Jerusalem Artichoke to Extract Heavy Metals from Municipal Sewage Sludge Amended Soil. Pol. J. Environ. Stud., 27(2), 513-527. https://doi.org/10.15244/pjoes/75200

3. Berdnikov O.M., Potapenko L.V., Datsko L.V., Datsko M.O. 2019. Vplyv system udobrennia na zapasy spoluk azotu v dernovo-pidzolystykh gruntakh. Visnyk ahrarnoi nauky, 6(795), 21-26. https:// doi. org/10.31073/agrovisnyk201906-03

4. Dubovyi V.I., Tabakaieva M.H., Shyshov B. O 2018. Vykorystannia kompostov iz osadu stochnykh vod pry vyroshchuvani silskohospodarskykh kultur yak okremoho vydu orhanichnykh dobryv. Insttutonal Repository of Polissia National University. Naukovo-innovatsiinyi instytut ekonomiky i ahrobiznesu, 316-318. http://ir.znau.edu. ua/ handle/123456789/9310

5. Geletukha G., Zheliezna T. 2021. Prospects for Bioenergy Development in Ukraine: Roadmap until 2050. Ecological Engineering \& Environmental Technology, 22(5), 73-81. https://doi. org/10.12912/27197050/139346 ISSN 2719-7050

6. Hetmanenko V.A., Skrylnyk Y.V. 2017. Naukovo-orhanizatsiini ta normatyvno-pravovi aspekty utylizatsii osadiv komunalnykh stochnykh vod (na prykladi yevropeiskoho dosvidu). Visnyk ahrarnoi nauky, 2, 43-49.

7. Hetmanenko V. 2016. Efektyvnist dii kompostiv na osnovi osadiv stichnykh vod na orhanichnu rechovynu chornozemu opidzolenoho. Visnyk ahrarnoi nauky, 71-73. https://doi.org/10.31073/ agrovisnyk201601-15

8. Hospodarenko H.M. 2015. Systema zastosuvannia dobryv. K.: IAE. 332

9. Hrytsuliak H.M., Lopushniak V.I. 2017. Osad stichnykh vod u systemi udobrennia verby enerhetychnoi: monohrafiia. Lviv: Prostir-M., 180.

10. Karbivska U., Kurgak V., Gamayunova V., Butenko A., Malynka L., Kovalenko I., Onychko V., Masyk I., Chyrva A., Zakharchenko E., Tkachenko O., Pshychenko O. 2020. Productivity and Quality of Diverse Ripe Pasture Grass Fodder Depends on the Method of Soil Cultivation Acta Agrobotanica 73(3). https://doi.org/10.5586/aa.7334

11. Kholodna A.S. 2016. Soil factors of floodplain soils that limit growth of energy crops. Gruntoznavstvo, 17, 43-49. https://10.15421/041612
12. Krutyakova V.I., Pilyak N.V., Dishlyuk V.€., Nikipelova O.M. 2020. Yefektyvnist zastosuvannya biodobriv na osnovi osadu stichnikh vod ochisnikh sporud $\mathrm{m}$. Odesa. Visnik agrarnoï nauki Prichornomor'ya, 3, 72-78. https://10.31521/2313-092X/2020-3(107)

13. Lamastra L., Susiu N.A., Tresian M. 2018. Sewage sludge for sustainable agriculture: contaminants, contents and potentyal use as fertylizer. Chemical and Biological Technologies in Agroculture, 5(1), 1-6. https://doi.org/10.1186/s40538-018-0122-3

14. Linxi Y., Quan S.H., Corscadden K., Udenigwe C.C. 2014 The prospects of Jerusalem artichoke in functional food ingredients and bioenergy production. Biotechnol Rep(Amst), 5, 77-88. https://doi. org/10.1016/j.btre.12.004

15. Long X., Shao H., Liu L., Li-ping L., Zhaopu L. 2016. Jerusalem artichoke: A sustainable biomass feedstock for biorefinery. Renewable and Sustainable Energy Reviews, 54, 1382-1388. https://doi. org/10.1016/J.RSER.2015.10.063

16. Long X.H., Huang Z.R., Huang Y.L., Kang J., Zhang Z.H., Liu Z.P. 2010. Response of Two Jerusalem Artichoke (Helianthus tuberosus) Cultivars Differing in Tolerance to Salt Treatment. Pedosphere, 20(4), 515-524.

17. Lopushniak V., Hrytsuliak H., Kotsiubynsky A., Lopushniak H. 2021. Forecasting the Productivity of the Agrophytocenoses of the Miscanthus Giganteus for the Fertilization Based on the Wastewater Sedimentation Using Artificial Neural Networks Ecological Engineering \& Environmental Technology, 22(3), 11-19. https://doi. org/10.12912/27197050/134867

18. Lopushniak V., Hrytsuliak H. 2021, The intensity of the heavy metals by topinambur in the conditions of the oil polluted areas. Iraqi Journal of Agricultural Sciences, 52(6), 1334-1345. https://doi. org/10.36103/ijas.v52i6.1473

19. Lopushnyak V.I., Hrytsulyak G.M., Bikin A.V, Polutrenko M.S., Kotsyubynska Y.Z. 2021. Prognostic Models of Panicum virgatum L. Using Artificial Neural Networks. Journal of Environmental Engineering, 22(11), 62-71. https://doi. org/10.12911/22998993/142958

20. Madzhd S.M., Bovsunovskyi Y.O., Tohachynska O.V. 2016. Naukovi metody kontroliu yakosty hruntyv yak indykatora ekolohichnoi nebezpeky na tekhnohenno navantazhenykh terytoriiakh. Visnyk KrNU imeni Mykhaila Ostrohradskoho. Vypusk, 2(97((1)), 115-121.

21. Onyshchuk D.M. et al. 2004. Novi ta maloposhyreni kormovi kultury Ukrainy: navch. posib Lviv: Ukr. tekhnolohii, 118.

22. Pacanoski Z., MehmetiA. 2020. The first report of the invasive alien weed Jerusalem artichoke (Helianthus 
tuberosus L.) in the Republic of North Macedonia. Agriculture and Forestry, 66(1), 115-127. https:// doi.org/10.17707/AgricultForest.66.1.12

23. Sloboda P., Lopushnyak V. 2017. Systema udobrennya topinambura. L'viv: Prostir M, 202.

24. Tekhnolohiia oderzhannia ta zastosuvannia orhano-mineralnykh dobryv na osnovi osadu stichnykh vod: rekomendatsii 2000. za red. K.O. Chebotko. Kyiv: Feniks, 53.

25. Rossini F., Provenzano M., Kuzmanović L., Ruggeri R. 2019. Jerusalem Artichoke (Helianthus tuberosus L.): A Versatile and Sustainable Crop for Renewable Energy Production in Europe. Agronomy, 9(9), 528. https://doi.org/10.3390/agronomy9090528

26. Ruf T., Audu V., Holzhauser K., Emmerling C. 2019. Bioenergy from Periodically Waterlogged Cropland in Europe: A First Assessment of the Potential of Five Perennial Energy Crops to Provide Biomass and Their Interactions with Soil. Agronomy, 9, 374. https://doi.org/10.3390/agronomy9070374

27. Yakist gruntu 1. Vyznachennia zahalnoho azotu v modyfikatsii NNTs INA im. O. N. Sokolovskoho : DSTU 4726:2007. [Chynnyi vid 2008-01-01]. K. :
Derzhspozhyvstandart Ukrainy, 2008, 14. (Natsionalnyi standart Ukrainy)

28. Yakist gruntu 2. Vyznachennia nitratno- ho i amoniinoho azotu v modyfikatsii NNTs IHA im. O. N. Sokolovskoho : DSTU 4729:2007. [Chynnyi vid 2008-01-01]. K. : Derzhspozhyvstandart Ukrainy, 2008, 14. (Natsionalnyi standart Ukrainy)

29. Yakist gruntu. Vyznachannia rukhomykh spoluk fosforu i kaliiu za metodom Kirsanova v modyfikatsii NNTs INA : DSTU 4405:2005. [Chynnyi vid 2006-07-01]. K. : Derzhspozhyvstandart Ukrainy, 2006, III, 7. (Natsionalnyi standart Ukrainy)

30. Yang L., He Q.S., Corscadden K., Udenigwe C.C. 2015. The prospects of Jerusalem artichoke in functional food ingredients and bioenergy production. Biotechnology Report, 5, 77-88. https://doi. org/10.1016/j. btre.2014.12.004

31. Yang S.P., Du G.L., Tian J., Jiang X.T., Sun X.M., Li Y., Li J., Zhong Q.W. 2020. First Report of Tuber Soft Rot of Jerusalem Artichoke (Helianthus tuberosus) Caused by Rhizopus arrhizus in Qinghai Province of China. Plant Disease. https://doi. org/10.1094/PDIS-02-20-0280-PDN 